\title{
8 Experiencer verbs
}

Experiencer verbs are probably the prototypical instances of gradable verbs. If a grammar presents an example of verb gradation, it is typically of experiencer verbs. Li \& Thompson (1989) list the examples in (1) in their discussion of the Mandarin Chinese degree intensifier hěn 'very.' They write: "Other than adjectival verbs, certain experiential verbs are the only ones that can take the adverbial modifier hěn" (Li \& Thompson, 1989, 339).
a. Tā hěn xiăng wǒ.
3SG very miss $1 \mathrm{SG}$
'S/He misses me a lot.'
b. Wǒ hěn pà gǒu.
1 SG very afraid dog
'I am very afraid of dogs.'
c. Wǒmen hěn zhùzhòng cáigàn.
1PL very emphasize competence
'We put a lot of emphasis on competence.'
(Li \& Thompson, 1989, 340)

Li \& Thompson's claim that hĕn is restricted to certain experiential verbs is too strong, as shown in (2). But even if $\mathrm{Li} \&$ Thompson's statement is too strong, it shows that experiencer verbs are conceived as prototypical instances of gradable verbs.

(2) ranhou dou hui hen bang ni o.

then all will very help you PART

'Then, they all will help you a lot.' (Chui, 2000, 48)

Experiencer verbs have triggered an extensive discussion on argument linking. Hence, there is a lot of literature dealing mostly with argument realization patterns of these verbs. I will briefly mention this discussion in 8.1, after specifying what I mean by the term 'experiencer verb.' In section 
8.2, I will discuss the semantics of two subclasses of experiencer verbs in more detail. This will provide the background for the discussion of verb gradation in section 8.3.

\subsection{Experiencer verbs - a general overview}

I have chosen the name 'experiencer verbs' for the class of verbs investigated in this chapter. This class of verbs covers Levin's (1993) 'psych verbs' as well as 'verbs of bodily state and damage to the body' (hurt, itch). Although psych verbs describe the "experiencing of some emotion" (Levin \& Grafmiller, 2013, 21), the verbs of bodily state included in this chapter describe the experiencing of bodily sensations like pain, hunger or coldness. What these verbs have in common is that one of the arguments of the verb has the experiencer role. Dowty $(1991,577)$ characterizes experiencers as sentient participants who neither act volitionally nor have some causal impact. This notion of experiencer is too narrow since I will also discuss experiencer verbs as admire which require agentive experiencers in some of their uses. One of the subclasses of psych verbs distinguished by Levin is 'admire verbs.' The experiencer of these verbs can act volitionally by actively admiring something, e.g. a painting. What these verbs have in common is that one of the arguments has the experiencer role. Verbs having an experiencer argument are more numerous than those discussed in this chapter. Perception verbs like hear, see and listen also have an experiencer argument but are excluded from the discussion. I restrict myself to verbs that express a psychological attitude or physical sensation since these verbs behave uniformly with respect to verbal degree gradation. ${ }^{1}$

Psych verbs have been the focus of much attention in linguistic literature as they are assumed to be puzzling with regard to argument realization. The apparent puzzle is based on examples like those in (3). Both verbs frighten and fear - describe the same type of psychological attitude, namely having fear. But they differ with regard to argument realization. Frighten realizes the experiencer argument as direct object, whereas fear realizes

I will not dive into a discussion of the nature of emotions and similar notions but assume that these can be characterized, from a linguistic point of view, simply as internal sensations or states. For a more elaborate and philosophical discussion of this topic see, for example, Ben-Ze'ev (2001). 
the experiencer as subject argument. The second argument - dog in these examples - is often referred to as stimulus argument.
a. The dog frightens the boy.
b. The boy fears the dog.

At first sight, both verbs seem to differ only with regard to the expression of their arguments. Verbs like fear are often called 'subject-experiencer verbs,' whereas those like frighten are named 'object-experiencer verbs' (Pesetsky, 1995, 19). This terminology highlights the differences in the realization of the experiencer argument these verbs show. The non-uniform linking of the verb's arguments causes a problem for approaches which assume that semantic roles are mapped to a unique syntactic position. A prominent approach of this kind is Baker's $(1988,46)$ 'Uniformity of Theta Assignment Hypothesis.' The data in (3) do not provide a problem if one does not assume that frighten and fear differ only with regard to argument realization but also with regard to their lexical semantics. Many researchers, such as Grimshaw (1990); van Voorst (1992); Pesetsky (1995); Härtl (2001); Van Valin (2005) among others, assume that frighten and fear differ with regard to their respective aktionsart classes and therefore dog has two different semantic roles in (3a) and (b). Although it seems to be common sense that verbs such as fear are states, there is much more heterogeneity in the analysis of frighten-type verbs. Grimshaw (1990) assigns them to the accomplishments class, van Voorst (1992) argues in favor of an achievement analysis, Härtl (2001) takes them to be activities and Butler (2003) as well as Rothmayr (2009) favor a (causative) state analysis. There is even a controversy whether these verbs are causative (Grimshaw, Van Valin) or not (Härtl). I opt for the view that subject-experiencer verbs and objectexperiencer verbs differ with regard to aktionsart and most importantly that the former are non-causative in contrast to the first mentioned class. But I turn later to a more detailed discussion of their respective aktionsart classes.

Experiencer verbs provide further interesting properties with regard to linking. Cross-linguistically these verbs display quirky case marking. Quirky case means "the marking of subjects and objects with cases other than the expected ones, e.g. dative, genitive, and accusative subjects, and dative and genitive objects" (Van Valin, 1991, 145). This can be illustrated 
by the German examples in (4) and (5). In (4) we have two experiencerobject verbs. The experiencer is marked with the accusative in (a), which is the canonical direct object case in German, but it is assigned the dative in (b). The examples in (5) are experiencer-subject verbs and the second argument is either accusative (a), dative (b) or genitive (c). The latter pattern is very restricted and it is doubtful whether the verbs in (b) and (c) can really be considered as being experiencer verbs in the sense mentioned above. For an extensive discussion of case marking patterns of German psych verbs see Wegener (1998) and Klein \& Kutscher (2005).
a. Er ängstigt mich.
3sG.NOM frightens 1sG.ACC
'He frightens me.'
b. Er gefällt mir.
3SG.NOM pleases 1sG.DAT
'He pleases me.'

(5)
a. Er mag mich.
3sG.NOM likes 1sG.ACC
'He likes me.'
b. Er vertraut mir.
'He trusts me.'
3SG.NOM trusts 1SG.DAT
c. Er gedenkt meiner.
3sG.NOM commemorates 1sG.GEN
'He commemorates me.'

Quirky case marking of experiencer verbs is attested in many languages, such as Italian Belletti \& Rizzi (1988); Arad (1998), Navajo Jelinek \& Willie (1998), Czech Filip (1996), Polish Rozwadowska (2007), Russian Sonnenhauser (2010), Spanish Whitley (1995); Arad (1998), Hebrew Arad (1998), Finnish Pylkkänen (1997), French Legendre (1989) and Japanese Matsumura (1996). ${ }^{2}$

The issue of argument linking seems to dominate the discussion on psych verbs and the distinction between frighten and fear, in particular,

See also Næss (2007, chapter 8) for a cross-linguistic discussion of case marking of experiencer arguments and Haspelmath (2001) for a discussion of the argument realization of experiencer verbs in Standard Average European. 
has triggered much discussion. There is a systematic relationship between frighten and fear, as can be seen in languages like Khalka Mongolian, in which frighten is derived from fear by causativation (6).

(6) Khalka Mongolian (Mongolic $<$ Altaic)
a. Ene oxin ter xüü-gees ai-j bai-na. DEM girl DEM boy-ABL fear-CON aux-npst 'The girl fears the boy.'
b. Ene xü̈ ter oxin-iig ai-lga-j bai-na. DEM boy DEM girl-ACC fear-CAU-CON AUX-NPST 'The boy frightens the girl.'

The importance of the fear/frighten pair is overestimated in the linguistic literature since these verbs are not prototypical for the class of psych verbs but caused much discussion. Levin \& Grafmiller $(2013,13)$ write: "Most experiencer-subject verbs lack experiencer-object counterparts referring to the same emotion and vice versa." Most experiencer verbs do not behave like frighten and fear, hence one does not have to look for a systematic relationship between subject-experiencer verbs and object-experiencer verbs. The lack of such an apparent relationship makes the linking differences between these two classes of verbs less puzzling.

In the next section, I discuss different types of experiencer verbs in more detail and relate the subclassification of experiencer verbs to an aktionsart classification.

\subsection{Types of experiencer verbs}

A first broad subclassification of experiencer verbs has already been mentioned: subject-experiencer verbs can be distinguished from objectexperiencer verbs. The first class covers verbs like German fürchten 'fear,' lieben 'love,' hassen 'hate,' bewundern 'admire' and bestaunen 'marvel at.' The second class consists of verbs like German ängstigen 'frighten,' ärgern 'annoy,' faszinieren 'fascinate,' erschrecken 'scare' and verblüffen 'baffle.' I will discuss these subclasses separately since the verbs in each class are heterogeneous regarding relevant semantic parameters. 


\subsubsection{Subject-experiencer verbs}

Subject-experiencer verbs are typically analyzed as stative predicates (Grimshaw 1990; Van Valin \& LaPolla 1997; Härtl 2001 among others). Since there seems to be agreement on the aktionsart classification of subject-experiencer verbs, I will not discuss this in detail but only illustrate it with an example taken from Maienborn (2003). She shows that the eventuality denoted by verbs such as hassen 'hate' cannot be picked up anaphorically (7), which - as discussed in chapter 3.2.1 - is a typical property of stative predicates.

(7) Catherine hasste Mozart-Arien. *Das geschah/ passierte

Catherine hated Mozart-arias this happened occurred während...

while

'Catherine hated Mozart arias. This happened/occurred while...' (Maienborn, 2003, 69)

In their discussion of the differences between subject-experiencer and object-experiencer verbs, Levin \& Grafmiller (2013) conclude that fear describes the mental state of an experiencer "as a disposition directed toward something" (p. 31) and not as "a direct response to an immediate stimulus" (p. 31). This characterization of fear follows from the types of entities which are typically realized as the stimulus argument. The authors write: "[...] the stimuli found with fear represent entities at which a particular emotion can be directed, and the authority inherent in many of these stimuli simply reinforces this. Inherently fear-inducing entities, events, or abstract notions need not be present in the immediate context, or even exist at all, making a direct causal connection between the stimulus and experiencer difficult to establish" (Levin \& Grafmiller, 2013, 30f.). The central point is that the referent of the stimulus argument is not the cause of the respective emotion rather it is some property of the entity, like its authority, that causes the experiencer to have an emotional response. The emotional state is dispositional-like in the case of object-experiencer verbs. In the case of subject-experiencer verbs, the emotion is a direct reaction towards the stimulus and the attitude is episodic rather than disposition-like (I will come back to this point in the next section). 
Subject-experiencer verbs can be paraphrased as indicated in (8). I use 's' as a placeholder for the respective attitude the experiencer has. The exact type of attitude is lexically specified by the verb. In the case of lieben 'love' it is 'love' and in the case of hassen 'hate' it is the attitude of 'hate.'

(8) Subject-experiencer verbs: Experiencer has attitude 's' with regard to stimulus

Subject-experiencer verbs express that the experiencer $x$ has an attitude $s$ with respect to the stimulus $y$. This is represented by the function ATTITUDE which takes the experiencer and the stimulus and returns the attitude $s$ the experiencer has. The respective attitude is further specified by a predicate as, for example, 'love(s)' in (9). A semantic representation of this type is given in (9) for the verb lieben 'love.'

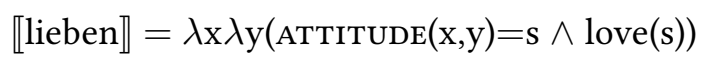

Most subject-experiencer verbs are transitive but some can only be used intransitively. Such intransitive uses are restricted to verbs of bodily state and damage to the body, as shown in (10). These verbs express bodily sensations and do not even have an implicit stimulus argument. Frieren 'be cold' only has an experiencer argument, whereas schmerzen 'ache, hurt' allows the experiencer to be implicit and the body part in which the pain is felt to be realized as the single argument of the verb. Since nouns denoting body parts are relational, as a body part always belongs to someone, the experiencer can be inferred as being the possessor of the body part. The experiencer is either expressed in an external possessive construction (b) or as a direct possessor of the body part (c).
a. Ich friere.
I be.cold
'I am cold.'
b. Das Bein schmerzt (mir).
the leg hurts me
'The leg hurts.' ('My leg hurts').

Klein \& Kutscher $(2005,3)$ mention that frieren 'be cold' also allows the experiencer realized in accusative rather than nominative case (Mich friert). There seems to be no semantic difference between both constructions, but the one with the experiencer in nominative case seems to be slightly more natural to me. 


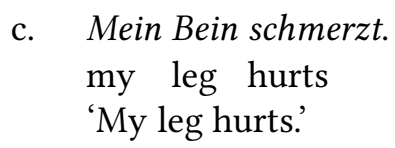

The semantic representation for intransitive subject-experiencer verbs is given in (11) for the example in (10a). The verb frieren simply means that the experiencer has a sensation of low temperature.

$$
\llbracket \text { frieren } \rrbracket=\lambda \mathrm{x}(\text { TEMPERATURE-SENSATION }(\mathrm{x})=\operatorname{low}(\text { TEMPERATURE }(\mathrm{x}))
$$

The subject-experiencer verb bewundern 'admire' has two different uses. Sentence (12a) expresses that the man feels admiration towards Van Gogh. In (12a) Van Gogh can be understood as being the painter but also in an abstract sense refering to the work of the painter Van Gogh. But there is also a more concrete reading, as in (12b). This sentence is ambiguous between the interpretation that the man feels admiration towards the respective painting or that the man is actively admiring the painting while, for example, standing in front of it. The first interpretation is possible with the painting being absent such that the sentence expresses a disposition of the man. In the second interpretation, the painting has to be present and the man perceives the painting. Although the man perceives the painting, he is admiring the painting too.
a. Der Mann bewundert Van Gogh. the man admires Van Gogh 'The man admires Van Gogh.'
b. Der Mann bewundert das Gemälde. the man admires the painting 'The man admires the painting.'

Härtl $(2001,186)$ mentions that in the latter reading, subject-experiencer verbs are used as activity predicates. Härtl $(2001,187)$ assumes that bewundern denotes an eventuality consisting of two subevents: a dynamic one which is a dynamic event of perceiving and a stative one which is being in an emotional state. The entity in the emotional state is the object of the perception. I assume a similar representation which is shown in (13).

$$
\begin{aligned}
& \llbracket \text { bewundern } \rrbracket=\lambda \mathrm{x} \lambda \mathrm{y} \lambda \mathrm{e} .(\operatorname{perceive}(\mathrm{e}) \wedge \operatorname{PERCEIVER}(\mathrm{e})=\mathrm{x} \wedge \\
& \operatorname{PERCEIVED}(\mathrm{e})=\mathrm{y} \wedge \operatorname{ATTITUde}(\mathrm{x}, \mathrm{y})=\mathrm{s} \wedge \operatorname{admiration}(\mathrm{s}))
\end{aligned}
$$


The verb bestaunen 'marvel at' is similar to bewundern but only has an agentive interpretation. It always requires some active perception of a stimulus and is not possible in a dispositional reading. Since the activity component can be modified, it shows that it is a meaning component of the verb. Härtl argues that an instrumental- $\mathrm{PP}^{4}$ can be used to modify the perceptional act (14).

\section{Peter bewundert gerade mit einer 3D-Brille die Konstruktion. Peter admires just with a 3-D glasses the construction 'Peter is admiring the construction with 3-D glasses.'}

(Härtl, 2001, 188)

There is a further reading of the agentive use of $(12 b)$, which is that the man expresses admiration by means of his behavior. This can be done verbally, by his facial expression or by other means. It is not clear to me whether the man has to feel admiration if he is expressing this feeling. Probably it is the default interpretation that if he is expressing admiration, then he also has the corresponding experience. But surely this is not necessary. Nevertheless, I propose the semantic representation in (15) for this reading, which I will call 'emotion expression' reading in the following. The semantic representation in (15) is very similar to the perception reading of (12b). The difference is that the first subevent is not a perceptual one, but one of expressing a content which is that the agent has a certain attitude towards the stimulus $y$.

$$
\begin{aligned}
& \lambda \mathrm{x} \lambda \mathrm{y} \lambda \text { e. }(\operatorname{express}(\mathrm{e}) \wedge \operatorname{AgENT}(\mathrm{e})=\mathrm{x} \wedge \\
& \operatorname{conTENT}(\mathrm{e})=(\operatorname{ATtitude}(\mathrm{x}, \mathrm{y})=\mathrm{s} \wedge \operatorname{admiration}(\mathrm{s}))
\end{aligned}
$$

\subsubsection{Object-experiencer verbs}

Object-experiencer verbs are basically transitive. We do not find underived intransitive experiencer verbs in this class, due to the fact that these verbs do not realize the experiencer argument in subject position. The subject argument can either be an effector or a stimulus but in each case, the emotional state of the experiencer is somehow caused by the referent of the subject argument. In chapter 3.2.2, I have shown that frighten allows

It would be more precise to call it an 'implement-PP' since subject-experiencer verbs are non-causative. 
for a causative paraphrase, whereas fear does not. The relevant examples are repeated in (16).
a. The dog frightened the boy.
$\rightarrow$ The dog caused the boy to feel fear.
b. The boy feared the dog.
$\nrightarrow$ The dog caused the boy to feel fear.

A further criterion for causativity, also discussed in chapter 3.2.2, is that only causative verbs license instrument-PPs, in the narrow sense of instrument. If a verb licenses an instrument argument, it usually participates in the instrument-subject alternation, which is exemplified for frighten in (17).

a. The dog frightens the boy with his teeth.

b. The teeth (of the dog) frighten the boy.

In (16a) and (17a) the dog can either actively frighten the boy by baring his teeth or it may simply cause the boy to be frightened by his mere presence, for example. Only if the dog is doing something to cause the frightening of the boy, can we speak of $d o g$ as an effector argument. If the dog is not actively engaged in causing the feeling, we can only speak of $d o g$ as a stimulus argument. In both cases, effector and stimulus stand in a different causal relation to the experiencer. This difference in causation is not captured by the causativity tests. Since this difference does not affect degree gradation, I will not discuss it further.

Frighten allows uses in which the emotion is not directed at the effector but at something else. This can be illustrated by the example in (18). In the example, they are the subject of frighten but the emotion is directed at grizzlies. The effector and the 'subject-matter,' as Pesetsky (1995) calls it, are distinct event participants in this example. In other cases, they can coincide.

They tried to frighten her with talk of grizzlies, but she just looked out the window at the low, treed terrain...

(Levin \& Grafmiller, 2013, 30)

The effector causes the respective emotion and the emotion can therefore be seen as a direct reaction to the effector. In contrast to subjectexperiencer verbs, emotions are not necessarily dispositional but can be 
episodic. An appropriate paraphrase of object-experiencer verbs looks like in (19). Basically, these verbs express a causation of an attitude the experiencer has. It is left open whether the attitude is directed at the effector which can be the case, but need not - or at something else.

(19) Object-experiencer verbs: effector causes experiencer to have attitude 's'

A semantic representation of the object-experiencer verb ängstigen 'frighten' is shown in (20). The representation consists of an unspecified causing event $e$ which is responsible for bringing about a state of emotion. The state is represented as the attitude of the experiencer $y$ towards a stimulus $z$. The stimulus argument is existentially bound as it is not a syntactic argument of the verb and, as discussed above, does not need to be identical with the effector argument.

$$
\begin{aligned}
& \llbracket \text { ängstigen } \rrbracket=\lambda \mathrm{x} \lambda \mathrm{y} \exists \mathrm{z} \lambda \mathrm{e}(\operatorname{cause}(\mathrm{e},(\operatorname{ATtitude}(\mathrm{y}, \mathrm{z})=\mathrm{s} \wedge \text { fear(s) }) \wedge \\
& \operatorname{EFFECTOR}(\mathrm{e})=\mathrm{x}))
\end{aligned}
$$

Object-experiencer verbs are basically transitive but they allow for an anticausative construction. As in the case of change of state verbs, the anticausative construction is marked by the reflexive pronoun sich as shown in (21). ${ }^{5}$ The experiencer is realized as the subject of the sentence, whereas the effector argument is not realized anymore. Rather a stimulus argument can be added in a prepositional phrase, as indicated in the examples. ${ }^{6}$
a. Der funge ängstigt sich vor dem Hund. the boy frightens REFL from the dog 'The boy is frightened of the dog.'
b. Der Mann ärgert sich über den Hund. the man annoyes REFL about the dog 'The man is angry about the dog.'

$5 \quad$ The subject-experiencer verb fürchten 'fear' can also be marked by a reflexive; in this case it does not have a decausativizing function. I will not discuss such marginal cases in the thesis and leave a systematic investigation of reflexive marking of experiencer verbs for future work.

6 Also see the discussion of reflexivized experiencer verbs in French in Pesetsky (1995, 97ff.) and Marín \& McNally (2005) on Spanish reflexively marked psychological verbs. 
The anticausative is marked in the same way as with change of state verbs. I assume that it is the same kind of alternation that can be observed with object-experiencer verbs and change of state verbs (see Alexiadou \& Iordăchioaia 2014, who make the same point in a discussion of the psych causative alternation in Greek and Romanian). Usually the discussion of anticausatives is restricted to change of state verbs and I already mentioned the existing analyses in chapter 6 . Whether object-experiencer verbs provide new data to this discussion must be left open for future investigation.

The anticausative use of object-experiencer verbs does not differ semantically from underived subject-experiencer verbs. This is no surprise given Levin \& Grafmiller's $(2013,13)$ statement that “[m] ost experiencer-subject verbs lack experiencer-object counterparts referring to the same emotion and vice versa." Anticausative formation fills a gap which is only lexically filled in some cases, such as that of frighten and fear.

Much like subject-experiencer verbs, object-experiencer verbs also show uses in which the first argument has an agentive interpretation (Grimshaw 1990, 23, Levin 1993, 191). Examples are the verbs amüsieren 'amuse', ärgern 'annoy' or erfreuen 'please. ${ }^{7}$ In (22a), das schlechte Wetter 'the bad weather' is a stimulus which stands in a causal relationship to the emotional state of the man. As the bad weather is not actively annoying the man, it is a stimulus and not an effector argument. In (b), das Kind 'the child' can either be an agentive effector or a stimulus argument. It could be the mere presence of the child that annoys the man or the child could intentionally do something to annoy the man, such as making noise or abusing the man. ${ }^{8}$
a. Das schlechte Wetter ärgert den Mann. the bad weather annoys the man 'The bad weather is annoying the man.'
b. Das Kind ärgert den Mann. the child annoys the man 'The child is annoying the man.'

For further examples of agentive object-experiencer verbs in German see Härtl (2001, 190).

This is in line with the RRG view of agentivity as merely being an implicature Van Valin \& Wilkins (1996). Hence, the thematic role 'agent' is a derivative notion from the more basic role 'effector'. 
A remark on the German verb amüsieren 'amuse' is in order since it also has an agentive anticausative use. In (23a), das Kind is either an agentive or non-agentive effector. Hence, it can amuse the man by intentionally doing something or unintentionally - such as by being clumsy. The anticausative use of amüsieren (b) also allows for different readings. One is the stative reading that the man is amused, the effector argument is omitted but an oblique stimulus argument can be realized. In addition, there are two agentive readings, one of which is the 'emotion expression' reading discussed at the end of the last section. In this reading, the man is expressing amusement through his behavior, facial expression or some other manner. In the second reading, the man is understood as making fun of the child. The man is not expressing his feelings, i.e., amusement, but rather he is engaged in other activities, such as joking. As an effect of these activities, he is amusing himself. Such agentive readings of anticausative object-experiencer verbs are very restricted, as is also the case for agentive readings of subject-experiencer verbs.
a. Das Kind amüsiert den Mann. the child amuses the man 'The child is amusing the man.'
b. Der Mann amüsiert sich (über das Kind). the man amuses REFL over the child 'The man is amused at the child. / The man makes fun of the child.'

A last type of object-experiencer verbs are so-called 'psych achievements.' For German, Härtl $(2001,191)$ mentions the two verbs erschrecken 'scare' and verblüffen 'baffle' as instances of this class. These verbs are clearly punctual, as they receive a repetitive interpretation if combined with durative adverbials (24). In (24), it is not a single baffling or scaring that lasts for an hour but the referent of the subject argument baffles or scares her friend repeatedly within hours.
a. Sie verblüffte ihren Freund stundenlang mit ihren she baffled her friend hours.long with her Geschichten.
stories
'She baffled her friend with her stories for hours.' 
b. Sie erschreckte ihren Freund stundenlang mit ihren she scared her friend hours.long with her Geschichten.

stories

'She scared her friend with her stories for hours.'

Achievements differ from semelfactives in that only the former are telic, whereas the latter are not. It is not easy to distinguish between these aktionsart classes but it does not matter for the following discussion whether the verbs are causative achievements or causative semelfactives. Erschrecken can also be used in the anticausative construction (25a), whereas verblüffen cannot (b). The anticausative of erschrecken is derived by adding the reflexive pronoun sich, whereas verblüffen does not take this pronoun. Rather it requires the reflexive construction sich selbst 'oneself.' In this case, the referent of the subject argument is understood as being the effector hence we get a reflexive and not an anticausative interpretation. Without sich the sentence is akward.
a. Er erschreckte sich vor ihren Geschichten.
he scared REFL of her stories
'He was scared by her stories.'
b. Er verblüffte sich selbst mit seinem Verhalten.
he baffled himself with his behavior
'He baffled himself with his own behavior.'

\subsection{Degree gradation of experiencer verbs}

The last section showed that subject- and object-experiencer verbs differ with regard to aktionsart. This difference, as mentioned in 8 , accounts for the different linking properties of these verbs. For the following discussion of verbal degree gradation, it is relevant to keep the aktionsart differences in mind. Subject-experiencer verbs are mainly stative and noncausative predicates, whereas object-experiencer verbs are dynamic and causative predicates. Object-experiencer verbs show a more or less systematic anticausative alternation, whereas both types of experiencer verbs also allow for an agentive interpretation of its first argument. The agentive reading is less systematic with subject-experiencer verbs than with object- 
experiencer verbs. As before, I will discuss degree gradation of subjectand object-experiencer verbs separately.

\subsubsection{Degree gradation of subject-experiencer verbs}

Subject-experiencer verbs are gradable by sehr as shown by the examples in (26). The verbs in (a) and (b) express an emotional attitude, whereas the one in (c) expresses a bodily sensation. In all three cases, degree gradation affects the intensity of the attitude or sensation.
a. Der funge liebt seine Mutter sehr. the boy loves his mother very 'The lad loves his mother very much.'
b. Er hasst seinen Nachbarn sehr. he hates his neighbor very 'He hates his neighbor very much.'
c. Ihm schmerzt das Bein sehr. him hurts the leg very 'His leg hurts very much.'

The paraphrase in (27) indicates that degree gradation affects the strength, i.e., intensity, of the attitude. Hence, degree gradation affects a gradable property of the experiencer's attitude. The relevant attribute chain is shown in (28). INTENSITY is linked to the eventuality through the implicit argument. In the context of degree gradation, the intensity scale can be retrieved from the conceptual knowledge associated with the lexically specified attitude.

(27) a. Subject-experiencer verbs: Experiencer has attitude 's' with regard to stimulus

b. Graded subject-experiencer verbs: Experiencer has strong/intense attitude 's' with regard to stimulus

$$
\lambda \text { s.(high(InTEnsity(ATtitude(s)))) }
$$

A semantic representation for the graded subject-experiencer verb lieben is shown in (29).

$$
\begin{aligned}
& \llbracket \operatorname{sehr} \quad \text { lieben } \rrbracket \\
& \operatorname{high}(\operatorname{InTEnSity}(\mathrm{s})))
\end{aligned}=\lambda \mathrm{x} \lambda \mathrm{y}(\operatorname{ATtitude}(\mathrm{x}, \mathrm{y})=\mathrm{s} \wedge \text { love }(\mathrm{s}) \wedge
$$


In (30), four Russian examples are shown which indicate that očen' functions as a degree intensifier for subject-experiencer verbs in Russian, too. In all four cases, očen' specifies the intensity of the respective attitude. Like in German, there is no difference whether it is a psychological attitude (a, b, c) or physical sensation (d).
a. Mužčina očen' boit-sja sobak-u. man.NOM very fear-REFL dog-ACC 'The man fears the dog very much.'
b. Mužčina očen' nenavidit svoego sosed-a. man.NOM very hate his.GEN neighbor-GEN 'The man hates his neighbor very much.'
c. Mal'čik očen' lubit mam-u. boy.NOM very loves mom-ACC 'The boy loves his mother very much.'
d. Noga mužčin-y očen' bolit. leg.NOM man.-gen very hurt 'The man's leg hurts very much.'

The verbs in (30) are imperfective and some allow the derivation of a perfective verb. In this case, an additional meaning component is contributed by the verbal prefix. For example, the imperfective bolit' 'hurt' becomes za-bolit' 'start to hurt' and ljubit' 'love' becomes po-ljubit' 'start to love' (31). Adding the prefix po-(31) derives a change of state predicate, the result state is the feeling expressed by the base verb. The intensifier further specifies the resulting state. I discussed similar cases for verbs of smell emission (discussed in the last chapter) and change of state verbs.

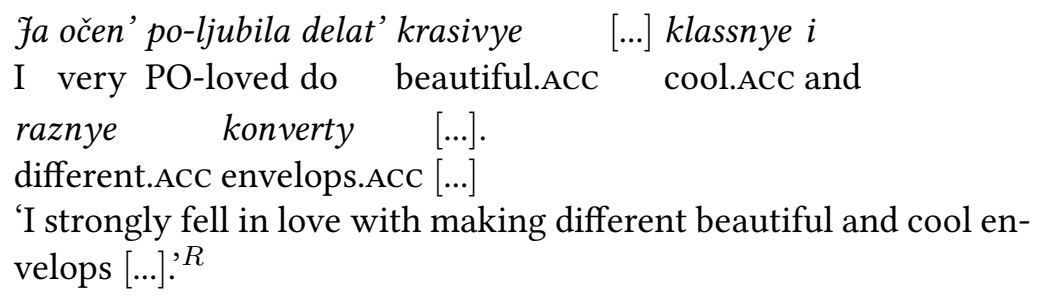

In French, degree gradation of subject-experiencer verbs has the same interpretation as in German and Russian. The example in (32) illustrates this point with the verb aimer 'love.' Beaucoup indicates that the intensity of the experiencer's love is 'high.' 
Il aime beaucoup cette langue.

he loves a lot this language

'He loves this language very much.'

As discussed above, some subject-experiencer verbs have not only a purely stative but also an agentive interpretation. Bewundern 'admire' is such a case and both of these readings are gradable by sehr. In (33a), sehr specifies the intensity of admiration the man feels for Van Gogh. Since (b) also allows for the pure stative reading, the same interpretation as for (a) applies.
a. Der Mann bewundert Van Gogh sehr. the man admires Van Gogh very 'The man admires Van Gogh very much.'
b. Der Mann bewundert das Gemälde sehr. the man admires the painting very 'The man admires the painting very much.'

For agentively interpreted verbs, there is a different interpretation of degree gradation. In an episodic reading, it can be said that the man is doing something which can be described as 'admiring.' It is expressed that the man is admiring the painting, which is illustrated, for example, by his behavior or facial expression. In the agentive reading of (b), sehr specifies the intensity of the expression of admiration. The behavior of the referent of the subject argument expresses strong admiration. It seems that this 'emotion expression' reading is always possible if the experiencer is conceived to be an agent. If one focuses on the agentive reading, sehr does not intensify the perceptual process. This is not unexpected since perception verbs such as sehen 'see' or wahrnehmen 'perceive' cannot be graded by sehr at all.

In (34), the paraphrases for the non-graded and graded agentive constructions are shown. The difference to the non-agentive reading is that it is not only stated that the experiencer has a certain experience but also that he is expressing this experience. I called this the 'emotion-expression' reading in section 8.2.1. Gradation applies again to the intensity scale but this time to the intensity of the expression of the feeling. A strong expression of a feeling does not necessarily entail that the experiencer has a corresponding intense feeling. The expectation that someone also has 
the attitude he expresses arises due to a Gricean implicature, as suggested by Sebastian Löbner (p.c.).

(34) a. Subject-experiencer verbs: Experiencer expresses attitude 's'

b. Graded agentive subject-experiencer verbs: Experiencer strongly expresses attitude 's'

In the agentive cases, gradation applies to a different gradable property than in the case of non-agentive subject-experiencer verbs. With agentive verbs, it is the intensity of the activity that is specified. In section 9.1.4 we will see that a similar interpretation arises with other verbs expressing activities, like schlagen 'hit' for example, as well. I assume that INTENSITY is a part of the manner component of gradable activity verbs but to answer the question how INTENSITY is integrated in the manner component, requires a decomposition of this meaning component which goes beyond the limits of this thesis.

\subsubsection{Degree gradation of object-experiencer verbs}

Object-experiencer verbs differ from subject-experiencer verbs in encoding a causal relation between the effector/stimulus and the feeling of the experiencer. This difference does not affect degree gradation; object-experiencer verbs admit degree gradation by sehr and, as in the case of subject-experiencer verbs, sehr specifies the intensity of the sensation. This is illustrated by the examples in (35). In (a), the dog not only causes the child to be frightened but also to be so to a high degree. Similarly in (b), the boy does not simply feel anger but the anger he feels has a high intensity.

a. Der Hund ängstigt das Kind sehr. the dog frightens the child very 'The dog frightens the boy very much.'

b. Seine schlechten Noten ärgern den fungen sehr. his bad marks annoy the boy very 'His bad marks annoy the boy very much.'

The examples in (35) can be paraphrased as shown in (36). Degree gradation specifies the strength of the experience, i.e., its intensity. As in the case of subject-experiencer verbs, the scale represents a property of the sensa- 
tion. Degree gradation activates the INTENSITY attribute from the conceptual knowledge that we have of the sensation lexicalized by the verb. In (37), the attribute chain that links intensity to the eventuality is shown.

(36) a. causative Object-experiencer verbs: Effector causes the experiencer to have attitude ' $s$ '

b. Graded causative object-experiencer verbs: Effector causes the experiencer to have a strong attitude ' $\mathrm{s}$ '

$$
\lambda \text { s.(high(INTENSity(ATtitude(s)))) }
$$

The semantic representation of graded ängstigen 'frighten' is shown in (38).

$$
\begin{aligned}
& \llbracket \text { sehr ängstigen } \rrbracket=\lambda \mathrm{x} \lambda \mathrm{y} \exists \mathrm{z} \lambda \mathrm{e}(\operatorname{cause}(\mathrm{e},(\operatorname{ATtitude}(\mathrm{y}, \mathrm{z})=\mathrm{s} \wedge \text { fear }(\mathrm{s}) \\
& \wedge \text { high(INTEnsity(s) }) \wedge \operatorname{EFFECTOR}(\mathrm{e})=\mathrm{x})
\end{aligned}
$$

As for subject-experiencer verbs, we find the same pattern of verbal degree gradation of object-experiencer verbs in Russian and in German. This is exemplified by in (39). The verb pugat' 'frighten' can be modified by očen', which in this case means that Fedor's vocation caused a high degree of fear in the Catholic circles.

$$
\begin{aligned}
& \text { Prizvanie Fedor-a na pol'sk-ij prestol očen' } \\
& \text { vocation.NOM Fedor-GEN PREP polish-ACC throne.ACC very } \\
& \text { pugalo katoličesk-ie krug-i. } \\
& \text { frightened catholic-ACC.PL circle-ACC.PL } \\
& \text { 'Fedor's vocation of the Polish throne frightened the Catholic cir- } \\
& \text { cles very much.' }
\end{aligned}
$$

The verb pugat' is imperfective but perfective verbs can be derived by prefixation. By adding na- to pugat', we derive the verb napugat' 'scare.' As (40) shows, the verb can be graded by očen', resulting in a specification of the intensity of the experiencer's fear.

$$
\begin{aligned}
& \text { Tak-ie novost-i očen' na-pugali Meri. } \\
& \text { such-Nom news-NOM very NA-frightened Mary.ACc } \\
& \text { 'Such news scared Mary very much. }{ }^{R}
\end{aligned}
$$

Also the affix $i z$-can prefixed to pugat' to derive a perfective verb meaning 'scare.' According to my informants, napugat' and izpugat' differ only in that the former is an unintentional scaring, whereas in the latter case it 
happens intentionally. Izpugat' is also gradable by očen' (41) and the interpretation is the same as for napugat'. It is the intensity of the feeling that is indicated as 'high.' Example (39) contrasts with (40) and (41) in aspect, the first one is imperfective and the latter two perfective, but there is no difference in the interpretation of degree gradation. Grammatical aspect does not affect degree gradation of eventive experiencer verbs.

$$
\begin{aligned}
& \text { Vasja vy-pryg-nu-l iz škaf-a i očen' } \\
& \text { Vasja.NOM VY-jump-SEML-PST from closet-GEN and very } \\
& \text { iz-pugal Vit-ju. } \\
& \text { IZ-frightened Vitja-acc } \\
& \text { 'Vasja jumped out of the closet and scared Vitja very much.' }{ }^{R}
\end{aligned}
$$

This short discussion of the prefixed variants of pugat' also leads to a discussion of punctual object-experiencer verbs. German punctual objectexperiencer verbs like erschrecken 'scare' and verblüffen 'baffle' are gradable, too. As for the durative object-experiencer verbs, degree gradation affects the intensity of the experience (42). There is no difference in degree gradation of durative and punctual object-experiencer verbs. Interestingly, degree gradation does not lead to an iterative interpretation of the eventuality, which is what happens with semelfactive verbs of sound and light emission. This is probably due to the fact that erschrecken and verblüffen are really achievements and not semelfactives and are therefore restricted to the denotation of single events (as discussed in section 7.4).
a. Das Geräusch erschreckte ihn sehr.
the sound scared him very
'The sound scared him a lot.'
b. Seine Noten verblüften ihn sehr.
his marks baffled him very
'His marks baffled him very much.'

German examples of graded anticausative object-experiencer verbs are shown in (43). The sentences in (43) are the anticausative correspondences of the ones in (35). As in the latter cases, sehr specifies the intensity of the experience. 

a. Das Kind ängstigt sich sehr (vor dem Hund). the child frightens REFL very for the dog 'The child is very frightened of the dog.'
b. Der funge ärgert sich sehr (über seine Noten). the boy annoys REFL very over his marks 'The boy is very annoyed about his marks.'

Degree gradation affects the same component of the causative as well as anticausative object-experiencer verbs. This can be seen by comparing the paraphrase for the graded anticausative object-experiencer verb in (44) with the paraphrase of the graded causative object-experiencer verb in (36). In both cases, it is the intensity of the experiencer's sensation that is graded. The link of the INTENSITY attribute to the eventuality is shown in (45).

(44) a. Anticausative Object-experiencer verbs: Experiencer has attitude 's'

b. Graded anticausative Object-experiencer verbs: Experiencer has a strong attitude ' $s$ '

$$
\lambda \text { s.(high(Intensity(ATtitude(s)))) }
$$

The semantic representation of a graded anticausative object-experiencer verb is illustrated by using the example of sich sehr ängstigen in (46).

$$
\begin{aligned}
& \llbracket \text { sich sehr ängstigen } \rrbracket=\lambda y \exists z(\operatorname{ATtitude}(\mathrm{y}, \mathrm{z})=\mathrm{s} \wedge \text { fear(s) } \wedge \\
& \text { high(InTEnsity(s) })
\end{aligned}
$$

It is not surprising that degree gradation of the causative and anticausative object-experiencer verbs is the same since the constant part is the state of having a sensation. Since the gradation scale is a property of the felt experience, it is part of the verb's meaning in both the causative and anticausative use. The same can be observed in Russian, which also marks the anticausative with a reflexive marker (47). Degree gradation applies to the INTENSITY attribute of the experiencer's sensation, too.

$$
\begin{aligned}
& \text { Ja často očen' pugal-sja ot neožidann-ogo šum-a. } \\
& \text { I often very frightened-REFL PREP unexpected-gen noise-gen } \\
& \text { 'I was often very frightened by unexpected noises. }{ }^{R}
\end{aligned}
$$


Finally, I turn to the question as to whether agentivity interacts with degree gradation of object-experiencer verbs. In (48), the effector argument can be conceived as intentionally and actively annoying the man. This is in contrast to (35b), in which case the effector argument seine schlechten Noten 'his bad marks' is inanimate and therefore does not give rise to an agentive interpretation. The agentivity of the effector argument does not affect degree gradation and the only admissible gradation scale, in this case, is given by the sensation's INTENSITY attribute.

$$
\begin{aligned}
& \text { Das Kind ärgert den Mann sehr. } \\
& \text { the child annoys the man very } \\
& \text { 'The child is annoying the man very much.' }
\end{aligned}
$$

Somewhat more complicated is the case of amüsieren, which licenses the agentive reading if the effector argument is animate. But the verb also licenses an agentive reading in its anticausative use. For the sake of illustration, I will discuss degree gradation of causative and anticausative amüsieren in parallel. In (49), we have the basic causative use of amüsieren, with an inanimate (a) and an animate effector (b). In the latter case, the effector also allows for an agentive interpretation. Irrespective whether the effector is interpreted agentively or not, sehr specifies the intensity of the amusement of the experiencer. So far, there is no difference to the data discussed above.
a. Der Film amüsiert den Mann sehr. the film amuses the man very 'The film is amusing the man very much.'
b. Das Kind amüsiert den Mann sehr. the child amuses the man very 'The child is amusing the man very much.'

In (50a), we have the plain anticausative use of amüsieren, which simply means that the man is very amused. This interpretation goes parallel to the one of the examples in (49). The example in (b) also allows for an agentive interpretation of der Mann. This gives rise to two different readings of the sentence. The first one is the 'expression' reading which has already been discussed in connection to agentively used subject-experiencer verbs. Degree gradation is interpreted in the same 
way as the corresponding uses of subject-experiencer verbs, it is the intensity of the expression of the respective sensation that is indicated by sehr. The second agentive reading of $(50 \mathrm{~b})$ is that the man makes fun of the child. It could be, for example, that the man is making jokes about the child. The activity is neither directed at the child nor is the child the object of the action. The child is more like the topic of the amusement and sehr indicates the intensity of the amusement of der Mann.
a. Der Mann amüsiert sich sehr. the man amuses REFL very
'The man is very amused.'
b. Der Mann amüsiert sich sehr (über das Kind). the man amuses REFL very over the child 'The man is very amused at the child./The man is making much fun of the child.'

\subsection{Conclusion}

In this section, I demonstrated that experiencer verbs do not form a homogeneous class of verbs. On the one hand, there are differences with respect to argument realization and on the other, there are different readings that are licensed by different subsets of experiencer verbs. It turned out that gradation is very homogeneous and always related to an intensity scale. The scale measures the intensity of the feeling of the experiencer. Degree gradation only has a different interpretation for some subject-experiencers if the subject referent has an agentive interpretation. In this case, the intensifier specifies the intensity of the activity of expressing a sensation rather than the intensity of the sensation itself.

Degree gradation of experiencer verbs neither interacts with grammatical nor lexical aspect. The Russian data have shown that the perfective/imperfective contrast is not relevant for the interpretation of verbal degree gradation of experiencer verbs. In (51), it is shown that ängstigen 'frighten' is atelic (a) and remains atelic if graded by sehr (b). Neither sentence means that after ten minutes the boy was (very much) frightened, rather the interpretation is that the dog starts to frighten the boy after ten minutes. We only get an ingressive interpretation, both in (a) and (b), and therefore the predications are atelic. 
a. Der Hund ängstigte den fungen in zehn Minuten. the dog frightened the boy in ten minutes 'The dog frightened the boy in ten minutes.'

b. Der Hund ängstigte den fungen in zehn Minuten sehr. the dog frightened the boy in ten minutes very 'The dog frightened the boy in ten minutes a lot.'

Similarly, it has been shown above that degree gradation does not lead to an iterative reading of punctual experiencer verbs such as erschrecken 'scare' and verblüffen 'buffle.' The fact that degree gradation does not interact with grammatical and lexical aspect as well as the homogeneity of degree gradation beside the heterogeneity of the verb class are two issues which I will discuss in more details in the next chapter.

Agentivity showed up to be relevant in the discussion of experiencer verbs. It was shown that agentivity may affect the reading of certain verbs but only marginally interacts with verbal degree gradation. Agentivity only intervenes with degree gradation if it triggers a meaning shift from a sensational towards an expressive reading of the verb. In all other cases, which do not induce such a meaning shift, agentivity is not an influencing property.

Finally, this chapter has shown the relevance of implicit semantic arguments for verbal degree gradation. As in the case of verbs of emission, experiencer verbs have an implicit semantic argument that licenses the activation of a gradable attribute. 